"This is an Accepted Manuscript of an article published by Taylor \& Francis in Feminist Media Studies in 2018, available online: http://www.tandfonline.com/

https://www.jstor.org/stable/10.15767/feministstudies.44.1.0126."

"The Place We've Always Wanted to Go But Never Could Find": Finding Woman Space in Feminist Restaurants and Cafés in Ontario 1974-1982

Author(s): Alexandra Ketchum

Source: Feminist Studies, Vol. 44, No. 1 (2018), pp. 126-152

Published by: Feminist Studies, Inc.

Stable URL: https://www.jstor.org/stable/10.15767/feministstudies.44.1.0126 


\section{"The Place We've Always Wanted to Go But Never Could Find": Finding Woman Space in Feminist Restaurants and Cafés in Ontario 1974-1982}

in A 1974 flyer, The founders of the soon-to-be-opened Clementyne's restaurant advertised the space as "the place we've always wanted to go but never could find." Clementyne's was intended as a self-described women's space in Toronto that was to be a restaurant during the day and a venue for events in the evenings. The upstairs offices were designated to be used by a variety of women's groups such as Other Woman Newspaper, Wages Due Collective, and the Women's Information Centre. The second floor was to have a meeting room, a smoking lounge, and a barbershop. The restaurant and café would be on the main floor, and the basement had a pool table. Difficulties over zoning laws ultimately prohibited Clementyne's from ever officially opening. However, the slogan "the place we've always wanted to go but never could find" brings to the forefront important questions about self-defined feminist restaurants and cafés in Ontario during the 1970s and 1980s. ${ }^{2}$ Who were these

1. “Newsflash: Women's Cafe,” n.d., Clementine's Café (Toronto, ON) 19741976, Archives Box 20 (hereafter, Clementine's Box 20), Canadian Women's Movement Archive, University of Ottawa (hereafter, cWMa).

2. I have intentionally avoided the wave metaphor in this article. As writers such as Joanne Meyerowitz have shown, the wave metaphor obfuscates feminist activism occurring after the passage of voting rights for women and activism done beginning in the 1960s. In this article, I am more concerned with the specific dates of action. See Joanne Meyerowitz, Not June 
spaces for? If a restaurant was designated a "women's space" or "woman space," what did that signify? What were these businesses' relationships with the larger economy?

Academics have paid far too little attention to the history of feminist eating establishments, and the few books and articles on the subject tend to focus on the United States and largely on the ways in which such businesses were used to build community. ${ }^{3}$ One of the most important books engaging with the significance of feminist cafés and restaurants is Anne Finn Enke's Finding the Movement. Enke focuses on the way that certain spaces, such as bookstores, clubs, sports fields, and cafés, shaped the feminism of the 1960s and 1970s. She emphasizes the way that feminist businesses and geographies worked within the urban spaces of Detroit, Chicago, and Minneapolis-Saint Paul. ${ }^{4}$ They argue that as women made commercial spaces activist, the newly created activist spaces both produced and simultaneously resisted exclusionary dynamics. ${ }^{5}$ The history of feminist restaurants and cafés brings attention to important issues

Cleaver: Women and Gender in Post-War America, 1945-1960 (Philadelphia, PA: Temple University Press, 1994).

3. While feminist restaurants have received little attention, academics have not ignored the role of restaurants in lesbian and gay social movements and community formation. George Chauncey's work on gay male culture in New York from 1890-1940, examines restaurants, cafés, and bars. Trisha Franzen has written about lesbians in Albuquerque, New Mexico, and has spoken about the important role restaurants and bars played in the formation of the lesbian community, noting that where Albuquerque lesbians chose to congregate between 1965 and 1980 said much about their social position. Nan Alamilla Boyd has looked at gay, lesbian, and queer bar culture in San Francisco up to 1965, emphasizing the importance of spaces that centered on food and drink for simultaneously political organizing and forging a sense of community. Warren Belasco's work highlights New York City feminist restaurant Mother Courage as an example of women's role in food activism in the 1970s. George Chauncey, Gay New York: Gender, Urban Culture, and the Making of the Gay Male World, 1890-1940 (New York: Basic Books, 1994); Trisha Franzen, "Differences and Identities: Feminism and the Albuquerque Lesbian Community," Signs 18, no, 4 (1993): 891-906; Nan Alamilla Boyd, Wide-Open Town: A History of Queer San Francisco to 1965 (Berkeley: University of California Press, 2003); Warren Belasco, Appetite for Change: How the Counterculture Took on the Food Industry (Ithaca, NY: Cornell University Press, 2014).

4. Anne Finn Enke, Finding the Movement: Sexuality, Contested Space, and Feminist Activism (Durham, NC: Duke University Press, 2007).

5. Enke uses gender-neutral pronouns. 
in Canadian history regarding feminist movements, social movements, political organizing, women's culture, and lesbian culture; these spaces were simultaneously critical venues for political organizing and community formation as distinct but related phenomena.

Examining feminist restaurants and cafés in Ontario is often concurrently a study of lesbian café culture, since both lesbian groups and feminist groups used the same venues. However, while there are intersections between feminist and lesbian spaces, the two were not always synonymous. Despite the relative lack of scholarly engagement with feminist restaurants, researchers have investigated other types of feminist businesses and women's spaces. Kathleen Liddle has written about the importance of feminist bookstores to the lesbian community in the United States. ${ }^{6}$ Her sociological study concentrates on the contribution of feminist bookstores to the lesbian community as important places for gathering and socializing. In turn, Meika Loe's article about the woman-owned-and-operated sexual products business Toy Box, established in 1977, reveals the complexities of running an "alternative" business during the late 1970s through 1990s and of balancing political ideals with profit needs. ${ }^{7}$ Loe reveals that when feminist companies were able to navigate the moral and ethical difficulties of creating a business, their success could not only be measured by profits but also by their ability to influence patrons and their communities. Kristen Amber Hogan has looked at the way that feminist bookstores built communities around print, the influence of feminist bookstores in the publishing world, and the importance of these spaces for the feminist community. ${ }^{8}$ My work on feminist restaurants echoes this sense of the community-building

6. Kathleen Liddle, "More Than a Bookstore: The Continuing Relevance of Feminist Bookstores for the Lesbian Community," Journal of Lesbian Studies 9, no. 1/2 (2005): 145-59. The loss of feminist bookstores was not just due to changing activist and social affiliations, but also to the rise of chain bookstores and online booksellers, which also resulted in the demise of many other independent bookstores.

7. Meika Loe, "Feminism for Sale: A Case Study of a Pro-Sex Feminist Business," Gender and Society 13, no. 6 (1999):705-32.

8. Kristen Amber Hogan, "Reading at Feminist Bookstores: Women's Literature, Women's Studies, and the Feminist Bookstore Network," (PhD diss., University of Texas at Austin, 2006); Cecilia Konchar Farr and Jaime Harker, This Book Is an Action: Feminist Print Culture and Activist Aesthetics (Champaign: University of Illinois Press, 2015). 
power of feminist spaces and bolsters claims that feminist business practices influence more than just economies. Focusing exclusively on restaurants and cafés, this article allows us to see the unique nature of these particular kinds of spaces and expands our understanding of how the geographies of women's spaces mattered to women, including, and perhaps especially, lesbians.

In this article, I emphasize the use of women-only or women-centered spaces within feminist cafés and restaurants and explore how the founders and patrons of these restaurants and cafés viewed women's spaces and negotiated what their locations meant. One of the consistent trends within Ontario's feminist restaurants during this time period was the constant questioning and renegotiation of the meaning of women-only or women-centered spaces. Throughout the period, intentional women-only spaces provided social, cultural, and political geographies for women. By the late 1970s however, the term "women's space" had become coded to mean a lesbian separatist space in most, although not all, circumstances - certain groups of Canadian liberal feminists still found women-only spaces to be important to political organizing and continued to label them as "women's spaces." This article explores the feminist restaurants and cafés Chez Nous, Clementyne's, and Three of Cups and contextualizes them within the larger history of feminist restaurants in Canada. In their creation and demise, these spaces underscore larger issues within women's movements and lesbian activism, as well as the role of language differences, nationalism, and mobility in Ontario in this period.

There are subtle but important distinctions between the terms used to describe women-centered spaces. "Woman space," also called "women's space," signaled a woman-owned-and-operated space, whether located in a permanent place or whether organized by a specific women's group that utilized multiple venues. Woman spaces/women's spaces sought to create a community for social, economic, and political organization. They were inherently political as they came out of discussions in the consciousness-raising groups of the late 1960s and early 1970s, which identified the need for geographies apart from men. When, at the end of the 1970s and into the early 1980s, the word "woman" in woman space began to be code for "lesbian" in many establishments, lesbian spaces that maintained the name "woman space" still upheld the tenets of woman space/women's space. Although these establishments 
now targeted lesbian participation by advertising themselves as woman space/women's space, this was not the same thing as a designated lesbian space, which, as will be discussed in more detail later, was not necessarily woman space. If a business described itself as a woman space or women's space during the timeframe examined, I used that term here to speak about the place. Other terms, such as "women-centered" or "women-friendly," I use to indicate places that were not necessarily owned or operated by women or that were not necessarily of a political or activist bent or that were not even exclusively for women, but that did have an ethos of fostering an environment that was welcoming and safe for women. Within all these categories, I discuss feminist spaces and lesbian spaces alongside one another, not to conflate the terms, but rather to honor the ways that the women were self-identifying.

There were many types of woman spaces in the 1970s and 1980s. However, in this article I focus on cafés and restaurants and how the founders of these establishments navigated the meaning of their space and their relationship with the larger economy. The first section looks at the history of women in spaces prior to 1970 . Next, the article traces the transformation of woman-space restaurants and cafés in Ontario into lesbian spaces. The third section explores why women-centered and women-friendly restaurants and cafés were utilized more often than exclusive woman-space places. The changing views on the need for women-only space in restaurants and cafés, matched with a constant tension with the male dominated systems of the local government and capitalism, caused many woman spaces to ultimately disappear.

\section{Why Woman space?:}

\section{a history of Women in spaces prior to 1970}

Woman spaces came out of a very specific intellectual and activist history, and they differed from prior spaces used by women's groups. While women in Ontario had previously been involved in social organizations, charity organizations, and activist groups, the kind of woman space discussed in this article arose from the discussions of consciousness-raising groups of the late 1960s and early 1970s. ${ }^{9}$ From this momentum,

9. See Alison L. Prentice, Canadian Women: A History (Toronto: Harcourt Brace Jovanovich, 1988), 331. 
women identified the need for separate spaces away from male-dominated establishments in order to escape oppressive formal restraints that regulated female socializing. Radical feminist and lesbian separatist theory in particular was very influential in advocating for these spaces.

In the early 1970s, feminists in Canada and the United States were formulating effective strategies to combat patriarchy and male aggression. Anthropologists Michelle Zimbalist Rosaldo and Louise Lamphere's 1974 work Woman, Culture, and Society argued that the greater the social distance between men and women in the public sphere, the greater the devaluation of women as members of society. ${ }^{10}$ As a result, they proffered two solutions: that more women strive toward entering formal workplaces and the public sphere in order to minimize the social distance between men and women, and secondly that women form a separate public sphere in order to create a new type of society.

This latter idea was heavily influenced by the work of Pam Allen, author of "Free Space: A Perspective on the Small Group in Women's Liberation," and by the consciousness-raising groups emerging at the time. In 1969, Allen's concept of "free space" for women's consciousness raising both promoted and reflected separatism found in spatial isolation. Whether or not the women who founded woman spaces had read these authors' works, their ideas were in wide circulation in the women's movements. By the early 1970s many feminist-identified women, both straight and lesbian, unapologetically promoted the idea of separate space in which to organize, socialize, dance, teach, learn, and develop new skills, authority, and autonomy from men. It was common, while at the same time radical, to seek what Enke terms "a space of our own." the same way that the promotional poster for Clementyne's restaurant claimed to be "the place we've always wanted to go but never could find," the organizers of woman spaces meant, in part, to create places apart from the world of men.

The desire to be apart from men resulted from both an intellectual and a physical need. Women, especially when unaccompanied by men, were viewed with suspicion in many mainstream bars, restaurants, and cafés before this time. Canadian women in the 1960s and 1970s had less

10. Michelle Zimbalist Rosaldo, Louise Lamphere, and Joan Bamberger, eds., Woman, Culture, and Society (Stanford, CA: Stanford University Press, 1974).

11. Enke, Finding the Movement, 10. 
access than men to public spaces due to both legal and social constraints. For more than a century, lone women in public space had been construed as sexually vulnerable at best and, at worst, as sexually suspect and punishable for their deviation from white, middle-class norms of domesticity. ${ }^{12}$ Stemming from prohibition laws from earlier in the twentieth century, many women in the 1960s and 1970s in Ontario were still discouraged from entering establishments where alcohol was served. ${ }^{13}$ It was no longer illegal for women to drink alcohol, but social stigma continued. Provincial differences affected whether or not women were as likely to enter a bar or café, but the bias against them was pervasive. By restricting women's access to places that served alcohol, provinces in part sought to create the appearance of a normative middle-class public, free from prostitution and lesbianism.

Even in spaces where women were allowed to drink or dine alone, many felt uncomfortable, as they would receive unwanted attention and overtures from men and were unable to seek support. Across the lines of race, class, gender, and sexual expression, a woman who was alone or unaccompanied by a man, especially at night, was met with suspicion and, sometimes, bodily harm. The combined effect of legal regulations and social barriers in the form of sexual harassment led women to want to create spaces of their own. ${ }^{14}$

Radical separatist lesbian theory was highly influential on the women's movements' desire for separate space for women, be they heterosexual or lesbian. The radical lesbian separatist feminist movement underscored women's relationships as the means for identity-based political organizing. In the account of one feminist scholar, Kathy Rudy, radical lesbian feminism was defined not only by sexual activity but also by women loving women as a "sentiment in feminist discourse that

12. Strong antiprostitution laws and the legal regulation of women's sexuality affected women's mobility. See Joan Sangster, Regulating Girls and Women: Sexuality, Family, and the Law in Ontario, 1920-1960 (Toronto: University of Toronto Press, 2001).

13. For an in-depth look at how prohibition influenced women's mobility and their ability to consume and distribute alcohol, see Craig Heron, Booze: A Distilled History (Toronto: Between the Lines, 2003), 200, 335.

14. See Andrée Lévesque, La norme et les déviantes: des femmes au Québec pendant l'entre-deux-guerres (Montréal: Éditions du Remue-ménage, 1989); Larry J. Siegel and Christopher Ray McCormick, Criminology in Canada: Theories, Patterns, and Typologies (Toronto: Thomson Nelson, 2006). 
lesbianism was the most legitimate way to act out [their] politics." ${ }^{15}$ For many radical lesbian feminists, feminism relied on finding and forging a female reality apart from the world of men. They thought that "by avoiding men and building a parallel, alternative culture, [they] were changing the world." ${ }^{16}$ Creating women-only spaces was a political act that created environments in which to further foster the development of radical lesbian separatist feminist politics.

Radical lesbian separatists promoted the virtuous nature of women-created communities in both urban and rural spaces. In rural settings, radical lesbian separatists founded communes, known as women's lands that relied for the most part on the ideology that all work should be shared. In practice, each commune developed a different system. For example, in 1973 three women from eastern Canada founded the Womanshare Collective, a space for lesbian separatists to gradually settle in southern Oregon in an attempt to realize their utopian dreams. These spaces were specifically for "women identified women. No men [were] on [that] land." ${ }^{17}$ Communes also gave radical lesbian feminist environmentalists the potential to live by all of their moral principles.

Although the model of communes was not restricted to rural settings, women-only communities influenced by radical lesbian separatist in urban environments often relied on a different form of separatism. In urban settings, although some women would choose to live together,

15. Kathy Rudy, "Radical Feminism, Lesbian Separatism, and Queer Theory," Feminist Studies 27, no. 1 (2001): 193, 195. See also, Radicalesbians, "The Woman-Identified Woman," in Radical Feminism, ed. Anne Koedt, Ellen Levine, and Anita Rapone (New York: Quadrangle, 1973), 240-45; Lucia Valeska, "The Future of Female Separatism," Quest 2, no. 2 (Fall 1975): 2-16; Charlotte Bunch, "Learning from Lesbian Separatism," in Lavender Culture, ed. Karla Jay and Allen Young (New York: Jove Books, 1978), 433-44.

16. Rudy, "Radical Feminism," 196.

17. Rosabeth Moss Kanter, Commitment and Community (Boston: Harvard University Press, 1972), 66. See also Catriona Sandilands, "Lesbian Separatist Communities and the Experience of Nature toward a Queer Ecology," Organization and Environment 15, no. 2 (2002). Sandilands argues, "Since 1974 [separatists] developed a distinct political-ecological culture to challenge the heterosexual, patriarchal, and capitalist organization of rural North America. Although lesbian separatism was founded on essentialist constructions of gender and nature, Oregon communities have developed, over time, a blend of lesbian principles and local environmental knowledge. This has produced a complex tradition of lesbian eco-political resistance" (131). 
separatism emphasized establishments that women could visit and utilize. Urban Canadian women who sought to create a women-only, separatist community founded and patronized women-owned, feminist businesses such as the Ottawa Women's Centre, health centers, bat- tered women's shelters, bookstores such as Toronto Women's Bookstore, women's community centers, cafés, auto-mechanics, self-defense gyms, printing presses, carpentry companies, snack shops, and restaurants. Separatism in this context did not necessitate moving to the countryside, although some feminists chose that route; separatism meant creating and supporting women-only spaces.

Feminist women of color in the United States and Canada, particularly black feminists, revealed how the emphasis on using women as the only criterion for building a community free from oppression elided oppressions based on class, race, age, religion, nationality, ethnicity, disability, and immigration status. ${ }^{18}$ However, as Julie Podmore has noted about the women-only space of lesbian bars in Montreal during the same period,

While in retrospect this practice may seem "essentialist" and limiting, at the time it was seen as necessary to ensure the rare control that these women had over commercial, "sexualized" space. Their women-only status, therefore, was an important territorial strategy that ensured freedom from harassment and voyeurs. Finally, these bars were embedded in a lesbian-feminist culture that was committed to increasing lesbian visibility by building "women's" culture. While this factor certainly limited the clientele of these bars, it did create an environment in which lesbians could produce bar culture on their own terms. ${ }^{19}$

We must be able to recognize the limitations of the actions and activ- ism of such feminists, while simultaneously being sympathetic to their motivations and circumstances. As Kathy Rudy also sees it, "We cannot understand the history or theory of contemporary feminism without

18. Alison M. Jaggar, Just Methods: An Interdisciplinary Feminist Reader (St. Paul, MN: Paradigm, 2008).

19. Julie Podmore, "Gone 'Underground'? Lesbian Visibility and the Consolidation of Queer Space in Montréal," Social and Cultural Geography 7, no. 4 (2006): 595-625. 
a deep appreciation for the infrastructure built by radical feminism." 20 This radical lesbian separatist ideology, alongside consciousness-raising groups, significantly influenced the creation of feminist cafés and restaurants as woman spaces.

\section{Women's space in action: ontario Woman spaces}

\section{Clementyne's}

In November of 1974, Chris Lawrence, Heather, and Holly signed a twoyear lease on a house at 342 Jarvis Street. ${ }^{21}$ They planned in March to open a restaurant that would later be known as Clementyne's. As previously mentioned, Clementyne's was a self-described women's space in Toronto that was intended to be a restaurant during the day and a venue for women's social and political organizing in the evenings. The founders wanted a license to serve alcohol initially for one night each weekend. The house had twelve-foot ceilings that were held up with ornate plaster carvings and lots of large windows that let in plenty of light. However, the property was in poor condition: the former tenants of the house had been male students at Ryerson with atrocious housekeeping skills and who had decorated the entire house in orange, hot pink, and black. The landlord promised to pay for materials necessary for refurbishment if the new tenants could "supply the woman power." 22 If the dream of Clementyne's was to be realized, it would be through the hands of the women who desired the place they've always wanted to go.

Clementyne's was paid for and built by the women who wanted it. A contemporary letter from one of the founders to her sister notes, "in November ' 74 four women got together over a few beers and decided that we, that is Toronto women, needed a café — an idea that had been floating around in everyone's head for sometime. We decided to do it ourselves." ${ }^{23}$ The women immediately set to work and made a list of one hundred and fifty other women they felt would share their concern. In

20. Rudy, "Radical Feminism," 200.

21. In many of the archival sources, first names are the only ones referenced. When both names are available they are used in the document.

22. "Newsflash: Women's Café," undated. Clementine's Box 20. cWMa.

23. "Dear Sister," Letter by collective to community members, November 1974, Clementine's Box 20, cWMa. 
two days, a letter was sent to each of these women asking them to each donate 50 Canadian dollars toward the project. Many on that original list responded, and a number promised money in the future. The show of strength and financial support allowed the self-described collective to move forward and secure the house on Jarvis street. Many women showed up and helped with the renovations, and after only one month of work, the founders felt that the space was "already becoming a place we can all be proud of." ${ }^{24}$ They continued to solicit donations from other women in the community, either in the form of money or supplies, such as a freezer, and also "any furniture that looks like it belongs in [your] great-grandmother's salon." ${ }^{25}$

The founders intended that the "money [was] to come from women who think it is a good idea and who want Clementyne's to exist." ${ }^{26}$ They insisted that they would build Clementyne's "without government grants and without costly bank loans" and wrote at the time that such a wish was possible if everyone contributed. ${ }^{27}$ Their reluctance to rely on bank loans came from the fact that many women during this period had difficulty securing their own sources of credit in Canada without the backing of either their fathers or their husbands. Relying on the collective input of other women who wanted to see this space in their community was an attempt to circumvent systematic patriarchal forces that would prevent Clementyne's from becoming a reality. Ultimately local governmental restrictions would prevent the space from ever officially opening.

Aside from the initial donations sought in order to finance the space, the collective of Clementyne's held a number of fundraising events in which they gave updates on the status of the development of the space. One fundraiser was on the evening of November 23, 1974, during the early stages of planning, and included drinks, entertainment (tap dancing, music, and performances), and much more.$^{28}$ On January 11, 1975, they held a women-only dance fundraiser. By March, their goal of opening had yet to be accomplished. Even in June they were still hosting fundraisers. On June 26, 1975, they held another licensed dance at 736

\footnotetext{
24. Ibid.

25. Ibid.

26. “Newsflash: Women's Café," n.d., Clementine's Box 20, cWMa.

27. "Dear Sister," Letter by collective.

28. Flyer for November 23, 1974, party, Clementine's Box 20, cWMa.
} 
Bathurst Street at the United Church. ${ }^{29}$ Through these events the Clementyne's collective built community and created their intended women's space before they even had a physical space of their own. The social focus of these events demonstrates that the importance of woman spaces was far more than just having a spot to sell food or feminist books. Community was in fact the product these spaces could sell and share.

The difficult process of choosing a name for Clementyne's elucidates how, in 1974, women's spaces represented a version of women that was not distinctly lesbian. Ballots were distributed in order to choose the name for the restaurant. Some of the proposed names were Patience and Sarah's Café, the Labyris, Delphine, Uppity Women Café, Sadie's, The Other Alice, A Room of Our Own, Womansoul, Women's Place, and The Lady's Club. ${ }^{30}$ When the winner was announced to be Uppity Women Café, there was much disappointment since many of the women in the collective were unsure of what that title meant. As a result, they

talked about it and decided that [they] wanted a name with no great literary value, no his/herstoric significance, and of no particular political persuasion. [They] wanted something plain that would be of meaning to any woman. [They] tossed around plain women's names: Mabel's, Jane's, Mary's and ended up with someone everyone knows of and very few could take exception with. ${ }^{31}$

The collective rejected Uppity Women Café as a name and settled on Clementyne's instead, with the idea that the name would not dissuade any women from coming. This rationale points to the fact that, in 1974, creating woman space was about emphasizing inclusiveness. However, while the term "woman space" was meant to be inclusive of all women, it actually had exclusive implications that led to the homogenization of women's experiences as those of white, able-bodied, middle-class women. Focusing on gender above other identity factors meant that the needs of the most privileged and powerful users of the space dominated decision-making. ${ }^{32}$

29. Announcement, June 26, 1975, Clementine's Box 20, cWMa.

30. Ballot to choose name, November 23, 1974, Clementine's Box 20, cWMa.

31. “Newsflash: Women's Café," n.d., Clementine's Box 20, cWMa.

32. Alice Echols, Daring to Be Bad (Minneapolis: University of Minnesota Press, 1989). 
The intention of the Clementyne's collective was to incorporate their establishment as a nonprofit women's club, which would allow the space to be male-free, legally. Legislation that was intended to ameliorate the segregation of women and men could be invoked to punish women who wanted separate spaces during a period when so-called shared space was in reality male-dominated space. Making a space a woman's club in Canada was a legal way of securing it as a women-only space. Selling club memberships circumvented issues of access based on gender and also allowed Clementyne's to fundraise.

However, as indicated by the flyer for the June 26, 1975, fundraiser event, Clementyne's had still not opened months after its inception, and its collective was having another meeting to release a status update. Ultimately Clementyne's never officially opened. Months after the founders had secured the lease on the property and invested months of effort repairing and refurbishing the house, they were informed by a city official that the area had been rezoned such that no new commercial businesses were allowed to open. ${ }^{33}$ When the founders had initially gone to the city prior to securing the lease, they had been assured that the building was in a commercially zoned area, and they were not informed that there was a special council motion stipulating that this house and others like it in the area were not to be converted to commercial use. ${ }^{34}$ Despite petitions to city hall, the zoning bylaws were not amended, and the original founders eventually gave up their vision and moved on to other projects in South America and beyond. ${ }^{35}$ Despite their efforts to create a woman space apart from mainstream society, they were still subject to provincial and federal legislation. Unless they were willing to break the law and open the space regardless, an approach that was seriously discussed among the collective, Clementyne's and other women's spaces would have to conform to laws that were written and passed by a male-dominated government.

33. Newsletter, "Introducing the new, updated, revised, modern cafÉ coLLectIve," November 1974, Clementine's Box 20, cWMa.

34. Ibid.

35. Ibid. 


\section{The Second Collective}

In the fall of 1975, women were still attending meetings and trying to revive the old Clementyne's collective, calling it Clementyne's Two. They talked about what they had learned from the mistakes of the previous Clementyne's collective and how to remake Clementyne's. ${ }^{36}$ Although the original café collective was officially defunct, the new collective wanted to be sure that the original founders' achievements were recalled with accuracy. The collective created a modest bank account for benefits and donations and decided to open a women's cultural center in the house at 342 Jarvis Street, subletting the house to a group of women who would live there for $\$ 50$ a month more than the existing rent in order to recover the money that had been put into it for refurbishments. The old collective passed on the remainder of the money in their bank accountapproximately $\$ 1,800$ — and the existing assets ("furniture, dishes, rent from 342 Jarvis, and a modicum of enthusiasm") to a new collective of women who wanted to begin again the development of a women's cultural center and café. ${ }^{37}$ On Sunday, October 5, 1975, this new group began to work on their ideas over a potluck supper, headed by Conn and Sherry. However, like the first collective, they spent "most of their time planning what their future would be like instead of doing anything, and they just dissipated." ${ }^{\prime 38}$

The Three of Cups coffeehouse was started in reaction to the inaction of the collective. Frustrated with the constant planning with little result, Paulette, a woman in the collective community, decided to put a coffeehouse together in two weeks' time. Many of the original collective believed that "if you make plans, the future is less vague, and there is less chance of failure if you plan ahead." However, Paulette had become exasperated with the endless planning- "planning and planning and not doing anything" - and felt that Clemntyne's "just died. Nothing was happening while they were talking." ${ }^{39}$ Although many feminists believed in creating women's spaces, the experiences of the Clementyne's collective illustrated how difficult actually creating these spaces

\footnotetext{
36. Ibid.

37. Ibid.

38. Interview excerpt about Three of Cups with Pat, Paulette, and Artemis, December 1976, Clementine's Box 20, cWMa.

39. Ibid.
} 
could be. Financial and practical barriers existed for all small businesses, but women-owned-and-operated spaces of the period faced additional difficulties due to sexism; these barriers had proved too difficult for Clementyne's founders to overcome.

The Three of Cups had its opening night on Boxing Day, December 26,1975 . The coffeehouse, which took its name from the tarot card about revolution and regeneration, in part became the center that Clementyne's was intended to be..$^{40}$ The founders of Three of Cups, referred to in their documents as Paulette, Dougal, and Artemis, realized that aside from making sure that zoning laws were on their side, "in order to have something big, you need people to have the energy. You need a good-sized collective, a lot of commitment, people who don't have other things to do." ${ }^{\prime 1}$ They had ideas and visions for a future, noting that they would have preferred a women's restaurant or a women's center but they needed people and energy, not only money, to keep such an endeavor up and running. Despite the community involvement in Clementyne's, Paulette, Dougal, and Artemis knew that woman spaces required a great deal of work. The founders of Clementyne's, in their minds, had spent too much time in the stage of imagination and not enough time on execution.

\section{Three of Cups}

The Three of Cups in part fulfilled the need for a women's space in Toronto, but the founders understood that it would not be able to fully be "the place you've always wanted to go." The coffeehouse was volunteer-run, despite many customers believing it was a more traditional business..$^{42}$ The opening times of the coffeehouse were limited because, despite having some support from the community, they needed much more, "enough that could turn the Three of Cups into a place that could be self-sufficient and well-organized and open more often." ${ }^{43}$ Especially at the beginning, the organizers of Three of Cups noted that the coffeehouses depended on "whether or not we could get it together personally every time the Three of Cups happens. Our survival depends on a few women-five at this point. The pressure is tremendous. If we have

40. Interview with Three of Cups collective, 1976, Three of Cups Box 105, cWMa.

41. Ibid.

42. Ibid.

43. Ibid. 
personality difficulties or if we are sick, we would just collapse. We didn't like that feeling." ${ }^{44}$ The creation of Three of Cups showed both the power and the problem of collectives.

The need for women's spaces could destroy the space itself. When a space was trying to cater to so many different needs, as was the case with Clementyne's, the space could also implode. In the collective's goal to appeal to "every woman," they were trying to be too much to too many people. Conversely, the Three of Cups showed the issue of what happens when too few people are involved; the collective could not last for too many years.

In some ways, Clementyne's provided a model of how a woman space did not have to be permanent to be effective. While Clementyne's had the goal of filling the floors of the house on Jarvis Street with women-run businesses, organizations, and a café/restaurant, it was the earlier fundraising events of dances and performances that provided a model for the Three of Cups coffeehouse. The Three of Cups coffeehouse only happened sporadically. However, each time events took place, they reshaped cultural geography. Woman space did not fully rely on permanent geographies but on social and political atmospheres filled with intent. While most of the spaces in my study took place in single locations, the decision by Three of Cups to host events in multiple locations demonstrated that woman space was not dependent on a fixed geography.

The Three of Cups also reflected another important theme within the feminist cafés and restaurants of the period. When organizers undertook a questionnaire to determine the future of Three of Cups, they asked their members if they should sell food, as previously they had been focused on serving beverages. The tensions over food and domesticity, which were not apparent in Clementyne's planning, could be seen with the Three of Cups. Food would never become the focal point for the Three of Cups. Indeed Clementyne's, the second Clementyne's collective, and Three of Cups all were far more about social interactions and activism and creating separate geographic places for an ever-shifting group that they called "every woman."

Importantly, feminist cafés and restaurants were not about alternatives to cooking. Initially, when I began this study, I thought that

44. Ibid. 
self-identified feminists founded these restaurants as one solution for the "cooking problem": the societal expectations that burdened women with the responsibility of shopping for food, cooking, preparation, and cleanup, which require numerous hours of effort on a daily basis. Many women liberationists wrote about the fear, guilt, stress, physical burdens, lack of respect, and lack of economic value associated with this labor. Other solutions to the cooking problem included buying ready-made foods, sharing housework responsibilities with male partners, advocating for wages for housework, joining communes (including but not limited to separatist lesbian farming communities), and founding food cooperatives to share cooking among groups of families. Socialist feminists, lesbian radical feminists, Marxist feminists, and what would be later known as eco-feminists advocated for different solutions. However, despite ostensibly being cafés and restaurants, the importance of food was downplayed in many of the Canadian feminist restaurants and cafés, and emphasis was placed on the space itself. Within their distributed literature and business notes, food was not the focus for these Toronto women's spaces. ${ }^{45}$

The questionnaire distributed by the organizers of Three of Cups, like the survey about the name of Clementyne's, demonstrated the ongoing self-reflexivity of women-centered cafés and restaurants in asking the customers and members about what they wanted out of the space. The changing answers mimicked other changes within the movements. After being founded in 1975, Three of Cups was still in business in 1978. As the years passed, the changes in the women's movement and lesbian activist and social communities could be seen in Three of Cups. While the idea behind Clementyne's, from which Three of Cups was founded, was about having a space for every woman, the meaning of every woman

45. This is not to say that food was unimportant; food is central to understanding the complexity of these feminist spaces. In order to understand feminist restaurants' relationship to domesticity and how one can assert feminism in a business that deals with food and that has a complex relationship with the kitchen (seen as a "traditional" place for women), it is helpful to be aware of the previous scholarship on Canadian household history, Canadian feminist movements, the background of Quebec and Ontario's social movements, feminist business history, and Canadian food history. See Alex Ketchum, "Counter Culture: The Making of Feminist Food in Feminist Restaurants, Cafes, and Coffeehouses," Cuizine: The Journal of Canadian Food Studies 7, no. 2 (2016). 
for Three of Cups began to mean lesbian women. Funds from Three of Cups' benefits were given to the Lesbian Organization of Toronto. ${ }^{46}$ Three of Cups sold memberships to the coffeehouses in order to legally keep the environment women-only. They gave their members the opportunity to join the collective if they were interested in becoming more involved with the organization. They continued to have events, such as concerts for women, around the city. Most of these events included dancing. In a questionnaire distributed to its members, the founders actually asked its members if they would be interested in having a coffeehouse without dancing, since so many of their events were dance based. Such changes were not necessarily smooth and often resulted in falling-outs among the participants. Brenda Laing resigned from the Three of Cups collective on May 2, 1978, in part because of her own personal finances but also due to her disagreement with the changes to the coffeehouse's structure that required a greater commitment of time.

The meanings ascribed to women's spaces changed dramatically from the late 1960s/early 1970s to the end of the 1970s/early 1980s. Women's space came more and more to imply lesbian space as the idea of what "woman" meant was challenged. As the women's movements changed, some feminists viewed women's spaces as a concept that did not recognize the multiple identities of women and the way that multiple oppressions shaped lived experiences so that the category "woman" was not the most important identity shaping women's life chances. The idea of a fully separate space for women as necessary for feminism was challenged, and by the end of the 1970s and into the 1980s, activism was less frequently organized or conducted in women's spaces. By the 1980s, the limitations of separatism as a political strategy became more evident, especially when it deprioritized issues of class, race, age, religion, nationality, ethnicity, disability, and immigration status. Many feminist communities were ripped apart by examinations focused on differences rather than their similarities. Furthermore, the emergence of postmodernist feminism and, later, queer theory reflected the limits of politics focused solely on identity. ${ }^{47}$ Nonetheless, lesbian separatist movements

46. St. Paul's Church event flyer, n.d., Three of Cups Box 105, cWMa. For more on the Lesbian Organization of Toronto, founded in 1976, see Prentice, Canadian Women: A History, 344.

47. Prentice, Canadian Women: AHistory, 207-8. 
let women highlight their interests in a way that was not assimilated within male-dominated power structures, or losing touch with feminist values, or tokenized in a male-dominated society. ${ }^{48}$

For the cafés and restaurants in which woman space became code for lesbian space, what made them different from lesbian bars? Both the cafés and restaurants, like the bars, organized dancing, music, and other forms of nighttime entertainment. They were all social spaces. Some, but not all, of the restaurants and cafés served alcohol at some, if not all, of the occasions. Lesbian bars in Toronto, like the Fly by Night Lounge, also served food. ${ }^{49}$ However, lesbian bar culture that dominated the lesbian scene in the late 1970s and 1980s was distinct from the woman space created in cafés and restaurants. One main difference was that, although both establishments could serve alcohol, the focus of the event had a different emphasis and the role of alcohol was different. While Fly by Night described itself as a "bar catering to women," this was really a coded form of saying "lesbian bar." ${ }^{50}$ According to its workers in 1980, it was the first and only lesbian bar in Toronto that had been created for lesbians, and was not frequented only by lesbians. Bar culture carried different connotations and led to different environments that were more charged with sex and violence. Bar culture was inundated with pick-up culture. Also the nighttime environment made women more vulnerable to sexual harassment the moment they exited the club's doors, especially due to Fly by Night's particular location close to a hotel where men would lurk, waiting to prey on the club goers. ${ }^{51}$ Although restaurants, bars, and cafés all provided social spaces, the type of political organizing that happened in restaurants and cafés was different.

Furthermore, while woman space was sometimes code for lesbian space, lesbian bars were not necessarily woman space. Heterosexual

48. See Estelle Freedman, "Separatism as Strategy" in Feminism and Community, ed. Penny A. Weiss and Marilyn Friedman (Philadelphia, PA: Temple University Press, 1995), 85-104.

49. Fly by Night flyer, n.d., Fly by Night Lounge - a bar catering to women (Toronto, ON) 1979-1980, Archives Box 31, folder 3 (hereafter Fly by Night Box 31), cWMa. The food was by "Night Sugar Mama's Munches" and included gazpacho, salads, muffins, spanakopita (spinach pies), sandwiches, a cheese plate, and baked goods.

50. Fly by Night leaflet, n.d., Fly by Night Box 31, cWMa.

51. Notice to customers, June 23, 1979, Fly by Night Box 31, cWMa. 
males oftentimes owned bars such as Fly by Night. Phil Stein, who had historically made most of his income off the "captive audience" of the gay community as former owner of the gay bar Blackbeard's, owned Fly by Night. In fact, Stein, angered by conflicts with his staff, shut down Fly By Night with these misogynistic words: "I don't let my wife tell me what to do in my home, and I won't let you girls tell me how to run my business." 52 This was after the women who worked in the bar "had sacrificed [their] former business independence [and then faced a] 50 percent reduction in wages." ${ }^{53}$ With only 15 minutes notice and no severance pay, Stein kicked out the staff. Fly by Night in 1980 was the central organizing space for the lesbian community, but clearly it was vulnerable in a way that woman space restaurants and cafés were not. After Stein shut down the bar, former staff and customers of the Fly by Night began discussions and expended "a lot of new energy directed towards re-establishing a space that will be ours - a space that we have control over as a community." ${ }^{54}$ The former workers and patrons wanted to create a community center for theater groups, arts, film groups, musical events and production facilities, political groups, social services, a café, and a laundromat. ${ }^{55}$ Essentially, the former employees of Fly by Night wanted to create a place for lesbians that was woman space - owned and operated by and for lesbians, since Toronto's lesbian bar culture at that point was not what they viewed as woman space.

\section{Chez Nous}

Woman space did not exist solely in the Toronto area. Chez Nous was a woman space in Ottawa where women could socialize, communicate, and organize. ${ }^{56}$ In 1978, an open meeting was called to discuss the future of the Ottawa Women's Centre, Canada's oldest women's center. ${ }^{57}$ The women in the community decided that they wanted the center to

52. Ibid.

53. Ibid.

54. Flyer for "Brainstorming Brunch," February/March 1980, Fly by Night Box 31, cWMa.

55. Ibid.

56. Chez Nous was initially located at 242 Besserer Street and later moved to 410 Queen's Street, Ottawa, Ontario.

57. News article in Upstream, 2 (May 1978), Chez Nous Box 509, folder 18 , cWMa. 
become more financially self-sufficient and able to survive without government support. A business committee, tasked with this goal, created Chez Nous, a small feminist café, which opened on the premises in February $1979 .{ }^{58}$ They hoped the revenue of the café would pay a staff person (or persons depending on the degree of success) to finance political activities and to encourage other feminist collective activities ${ }^{59}$ Unfortunately, difficulties connected to their application for a liquor license threw them into financial trouble, which forced them to close in May 1980.

Although "woman space" had become code for lesbian establishments by the end of the 1970s, Chez Nous was a woman space that was in fact open to and designed for all women regardless of sexuality. The liberal feminist influences apparent in the center's work sought to effect legal and social change in a way that made a broad usage of the term "woman space" still useful. Chez Nous was a self-reflexive project of the Ottawa Women's Centre. In the aforementioned January 1978 meeting to discuss the dropping levels of participation in the women's center, individual women and feminist organizations of Ottawa discussed what function the center should serve. A series of meetings with a similar goal took place throughout that winter. On February 14, there was a meeting dealing with issues of the feminist critique of the center, asking if responding to local, regional, or national feminist issues was part of the center's job. They wondered if their strong engagement with feminist activism would deter apolitical women from attending. ${ }^{60}$ The Ottawa Center kept copious typewritten documents, indicating that at almost every meeting that winter, the organization sought to define the purpose of the space. Subsequent to the February 14, 1978, meeting, Louise Leclair presented to the policy committee her desire to set up a café with an adjacent activities area while at the same time providing space for the women's center to exist. She was part of the group of women who "formulated the idea of the women's centre as a self-sustaining organization. A proposal [was] submitted to the Policy Committee outlining a cafétype business; open to women only and offering light lunches, games and eventually beer and wine." ${ }^{16}$ The business revenue would be obtained

58. Meeting minutes, May 8, 1978, Chez Nous Box 509, folder 18, cWMa.

59. Proposal, 1978, Chez Nous Box 512, folder 16, cWMa.

60. Meeting minutes, February 14, 1978, Chez Nous Box 509, folder 18, cWMa.

61. Proposal, 1978, Chez Nous Box 512, folder 16, cWMa. 
from the sale of food, beer and wine, and memberships, which would be based on what each woman could afford. The café would include space for meetings, a library, and eventually a bookstore. ${ }^{62}$ As a result, they would need a new space for the center to accommodate these changes. Sheila Cilhooly and Louise Leclair then began to concretize the proposal by looking for suitable accommodation, and initial costing were done.

However, it soon became evident that more information was needed. As a result, a larger group of people came together to do this work. Meetings were held every Thursday evening at Louise Leclair's house with a large group of women dedicating their time and efforts. After more research was done, a costing proposal was pulled together. Discussions were also made about legal, financial, and structural questions. Unlike other woman spaces, the organizers of Chez Nous fully researched every aspect of the legal and economic necessities for functioning. As many of the women had no prior job experience in running an independent business, they reached out to other women involved in the center and to friends for legal and business advice. They also were meticulously organized and, apart from keeping intensely organized notes, they formed a variety of committees, such as a business collective and a policy committee, and each committee was governed by voted-upon bylaws that regulated how votes were determined, how positions were designated, and how often a committee would have to meet. These changes required them to draw up an amended version of their constitution. Chez Nous was far more organized than woman spaces earlier in the period such as Clementyne's. For example, the founders of Clementyne's never created a thirty-page business proposal, in comparison. This shift to becoming more organized mirrored changes in the larger women's movements. In general, women's political organizing throughout the 1970s became more and more organized. Feminist activism had transformed from consciousness-raising meetings in someone's living room to national organizations campaigning for a variety of causes. However, the goal of self-sufficiency from bank funds and government grants had not changed.

One flyer described Chez Nous as “a woman's club being organized by the Ottawa women's centre, not an exclusive club — but a club

62. Ibid. 
for ALL women. At Chez Nous, a sandwich might be bought or a game of pool played - an evening might be spent listening to the poetry or music of women - a painting, photograph or book might be bought." ${ }^{63}$ That same flyer told women to "join us - find out more about YOUR club." The founders believed that the "cause of women's liberation would be furthered by establishing a milieu where all women could meet, by providing space for political organization and small collective projects, by supporting women artists, photographers (hanging and selling work for very reasonable consignment fee) by making other feminist material available." They had "a very strong feeling that a market for a women's meeting place exists." Serious consideration was given to aesthetics "(without pretentiousness), solid business practices (while considering that generally women are an army of the poor)," and quality in the goods being served so as to encourage a growing rather than a diminishing clientele. They realized that although a lot of hard work was required, "a supportive women's community [was] of utmost importance." 64

Unlike in the cases of the restaurants and cafés in Toronto, Ottawa had a large francophone population. Although Canadian feminisms are strongly influenced by the writings of feminists from the United States, Canadian feminisms have differences. Francophone women, in particular, as noted by historian Sean Mills, were also greatly influenced by the writings of French feminists. Negotiating both language and political differences between anglophone and francophone Canadian feminists was most apparent in the province of Quebec, but was also important in Ontario and New Brunswick (provinces with large francophone populations). ${ }^{65}$ The collective greatly encouraged francophone participation, advertised bilingually, and discussed other ways to attract francophone women. ${ }^{66}$ The theme of collectivity continued from other woman spaces from earlier in the period. However, the ways that they organized were

63. Flyer, September 23, 1978, Chez Nous Box 512, folder 17, cWMa.

64. Proposal, 1978, Chez Nous Box 512, folder 16, cWMa.

65. A full discussion of these complexities is beyond the scope of this article. For further reading, see Sean Mills, The Empire Within: Postcolonial Thought and Political Activism in Sixties Montreal (Montreal: McGill-Queen's Press, 2010) and Geneviève Pagé, "Gender at the Crossing: Ideological Travelings of US and French Thought in Montreal Feminism," Feminist Studies 42, no. 3 (2016): 575-603.

66. Meeting minutes, May 1, 1978, Chez Nous Box 512, folder 16, cWMa 
now more formalized. In order to restrict membership to women, it was necessary to issue memberships for the café. A membership drive was undertaken, fees were staggered, and flexibility was exercised in dealing with visitors from out of town.

Although their goal was to open by June 1, 1978, Chez Nous did not officially open until February of 1979, twelve months after the initial meeting. In part the delay was caused by the difficulty of finding a suitable space. Furthermore, the business had a hard time securing a liquor license from city hall, despite its status as a club, which made it eligible for a beer and wine license. Organizers had not intended on waiting to have this license to open, although they suspected that operating as a dry café would not lead to their desired financial stability. The organizers thought that activities such as pool, pinball (redone with feminist cover plates), games, and women's music would keep members interested. In spite of receiving \$2,679 Canadian dollars in memberships from 80 people and $\$ 800$ in building funds they had not even scratched the surface of financial independence. This caused them to ask, "Aren't we ashamed?" ${ }^{67}$ One member, Gail Toy, who agreed to set up books for payroll, bills, etc., suggested that they open immediately on full hours, hire another person, and consider buying things oncredit.

Despite their goal of not depending on banks, they resorted to credit. Creating the restaurant, remodeling, and buying equipment was costlier than they first thought, despite all of their planning. They discussed their capital expenditure with charts and looked at other women's clubs. They decided to host fundraising events in order to not rely on the bank. Unfortunately, one such event held on August 26, 1978, actually cost more than they raised, and they lost money on the event. ${ }^{68}$ Nevertheless, the grand opening took place on February 4, 1979, and apparently "everyone agreed that the opening went well. [The] financial statement worked out to a profit of $\$ 175.00$ for Sunday alone." ${ }^{99}$ The collective agreed that activities were necessary for keeping members interested. While they noted the "menu seems to be working out alright; sandwiches and croissants are popular," memberships weren't selling

67. Ibid.

68. Business Collective Meeting minutes, 1978, Chez Nous Box 512, folder 18, cWMa.

69. Meeting minutes, February 8, 1979, Chez Nous Box 509, folder 18, cWMa. 
at the expected rate. ${ }^{70}$ However, over the first couple of months, there was reason to be optimistic: "members seem to be increasing ... ten new memberships were sold last week." ${ }^{.71}$ At the April 25, 1979, meeting organizers were worried about the prospect of a quiet summer, as they had to wait until the fall for liquor licenses. By the May 15 meeting, the minutes note, "finances are so so, [\$]1,000 left after expenses. Not much but at least we're still operating." ${ }^{.72}$ The organizers reassured themselves as the minutes record, "Gail Toy says not to worry this happens to all small businesses trying to get off the ground. We have no debts and we're in the black." However, the July 2 meeting minutes note, "things are very quiet at Chez Nous. We're holding but just barely." "73 Organizers continued to persevere, and at the August 15 meeting they were strategizing new ways to get people into the café. Ideas included opening for lunch and convincing Algonquin College to use their library space to give a course on women in business. To make financial matters worse, they continued to be "getting run around from City Hall" on the liquor licensing and were unable to benefit from the greater profit margin of alcohol ${ }^{74}$ While resorting to depending on a bank was undesirable, the collective of Chez Nous had the privilege of being able to secure credit, unlike other woman spaces of the time period.

Ultimately, the expenses of running Chez Nous were too great. The collective members complained of being overworked and underpaid. ${ }^{75}$ While such conditions were tolerable for a short period of time, the stress proved to be too much, and the café eventually folded. Despite the need for woman space, feminist cafés and restaurants were still beholden to the general economy. In general, small cafés and restaurants have a hard time sustaining themselves, especially those that make their menu items as reasonably priced as possible. Although women's spaces were a different kind of space, they were still vulnerable to the larger factors of the market place.

70. Meeting minutes, May 15, 1979, Chez Nous Box 509, folder 18, cWMa.

71. Meeting minutes. February 20, 1979, Chez Nous Box 509, folder 18, cWMa.

72. Meeting minutes, May 15, 1979, Chez Nous Box 509, folder 18, cWMa.

73. Meeting minutes, July 2, 1979, Chez Nous Box 509, folder 18, cWMa.

74. Meeting minutes, August 15, 1979, Chez Nous Box 509, folder 18, cWMa.

75. Handwritten note from April, 1979, Chez Nous Box 509, folder 18, cWMa. 
Chez Nous set itself apart from the Toronto woman spaces in a variety of ways. The first was that the founders were trying to make an inclusive woman-only space at the end of the 1970s when the idea of woman space had somewhat fallen out of favor outside the lesbian community. Chez Nous was aware of class differences and language differences within the women's population of Ottawa, although race was never mentioned specifically. Also Chez Nous, unlike Clementyne's and Three of Cups, discussed their menu thoroughly. They listed all of their desired menu items and discussed prices. The food was to be simple to prepare in order to lower the burden on the women who worked in the space. They made sure that the food was reasonably priced because they understood the economic disadvantages that many Canadian women faced, especially working women who often made less money than their male counterparts. By making their menu reasonably priced, they saw the food choices as feminist. Thus, unlike the Toronto establishments, the product they were selling was specifically feminist, rather than just selling the experience. Chez Nous seemed more like a business of the earlier 1970s. However, the founders' awareness of certain intersectionalities of the oppressions of gender, class, and language that showed in its menu was indicative of its period. The founders still found woman space as a needed place for all women rather than just lesbians.

The woman spaces Clementyne's, Three of Cups, and Chez Nous, while all different, were examples of feminist economic experimentation. In trying to define themselves as businesses, they hoped to be independent of the male-dominated economic structures of the banks, in part out of necessity and also due to their philosophy. All of these businesses struggled economically, which can often be the case for a regular café or restaurant. They were forced to deal with the social, governmental, and economic realities of the larger world. Their difficulty in accessing liquor licenses speaks to a larger history of Canadian morality and women's mobility. The constant questioning and redefining of the spaces were part of what made them woman spaces, whether or not that space was for all women or for lesbians.

\section{conclusion}

By 1981, most woman spaces in Ontario had already closed. It was not until November 1987 that Toronto welcomed the opening of Gaia's Garden Café at 24 Baldwin Street, a new "womyn's space” that provided 
"natural food, womyn's entertainment, and art." A flyer announcing the opening notes that Gaia's was "feminist owned and operated." The founders advertised positions for hire, indicating that it was not a collective. ${ }^{76}$ Even in the small amount writing on the flyer, emerging social trends and changes to earlier ideas about women's space are evident. The use of natural foods reflects trends in ecofeminist ideology. This single flyer says so much about the changing ideas of women's space, feminist movements, and place.

Initially women's space/woman space was intended for straight, gay, and bisexual women to have a place away from men. Despite legitimate critiques of these spaces, the emphasis made on women's relationships with women in women-only spaces gave rise to a large variety of feminist readings, concerts, dances, and other cultural events. These activities often took place in women-owned feminist businesses such as bookstores, women's centers, cafés, and restaurants, which served as spaces for political organization and community.

The meaning of women's space/woman space transformed over time. Despite changing meanings, the continuing emergence and disappearance of these spaces showed their political usefulness. Woman space was time and resource intensive. As a result, most spaces would only last for a few years. Woman space was not fully necessary for political organizing by feminists throughout all of Canada. While many woman space restaurants and cafés went out of business in only a few years, this did not mean that they were failures. Woman space allowed for and fostered a certain kind of community for socializing, economic exchange, and political organizing that played an important role in the women's movements. Despite woman space creating alternative spaces, these experiments were still susceptible to mainstream economic patterns and governmental legislation, which curtailed some of theirdreams.

76. Gaia flyer, Archives Box 31, cWMa. 